\section{Regards sur l'économie allemande}

Bulletin économique du CIRAC

$70 \mid 2005$

Varia

\title{
Impôt sur le revenu : une répartition assez homogène
}

\section{Isabelle Bourgeois}

\section{OpenEdition}

1 Journals

Édition électronique

URL : http://journals.openedition.org/rea/2143

DOI : 10.4000/rea.2143

ISBN : 978-2-8218-0836-2

ISSN : 1965-0787

\section{Éditeur}

CIRAC

Édition imprimée

Date de publication : 1 mars 2005

Pagination : 35

ISSN : 1156-8992

Référence électronique

Isabelle Bourgeois, "Impôt sur le revenu : une répartition assez homogène », Regards sur l'économie allemande [En ligne], 70 | mars 2005, mis en ligne le 16 décembre 2008, consulté le 15 septembre 2020. URL : http://journals.openedition.org/rea/2143

Ce document a été généré automatiquement le 15 septembre 2020

(C) CIRAC 


\section{Impôt sur le revenu : une répartition assez homogène}

\section{Isabelle Bourgeois}

1 Le $1^{\mathrm{er}}$ janvier 2005 est entré en vigueur le dernier volet des réformes fiscales adoptées depuis le 14-07-2000. Il se résume pour l'essentiel à l'abaissement du barème de l'impôt sur le revenu aux deux extrémités: le plafond est passé de $45 \%$ à $42 \%$; le taux plancher est désormais établi à $15 \%$ (contre $16 \%$ ). Le seuil d'imposition est demeuré inchangé; il avait été rehaussé à $7664 €$ en 2004 (voir REA 65/04). Ces mesures, destinées à abaisser la charge fiscale pesant sur les foyers (ménages et entreprises) à revenus faibles et moyens, devraient se traduire par un recul des recettes fiscales de l'ordre de 6,5 milliards $€$ cette année.

\begin{tabular}{|c|c|c|c|}
\hline \multicolumn{4}{|c|}{ Contribution des différentes tranches de revenus au produit de l'IR en 2004} \\
\hline \multirow[t]{5}{*}{$\begin{array}{l}\text { Revenus } \\
\text { supérieurs }\end{array}$} & $\begin{array}{l}\text { Part des } \\
\text { foyers ... }\end{array}$ & $\begin{array}{l}\ldots \quad \text { au revenu annuel } \\
\text { supérieur à ... }\end{array}$ & $\begin{array}{l}\text {... et leur contribution au produit } \\
\text { de l'IR }\end{array}$ \\
\hline & $5 \%$ & $85400 €$ & $41,4 \%$ \\
\hline & $15 \%$ & $57950 €$ & $61,0 \%$ \\
\hline & $25 \%$ & $46550 €$ & $72,9 \%$ \\
\hline & $35 \%$ & $38100 €$ & $81,4 \%$ \\
\hline \multirow[t]{3}{*}{$\begin{array}{l}\text { Revenus } \\
\text { inférieurs }\end{array}$} & $\begin{array}{ll}\text { Part } & \text { des } \\
\text { foyers ... } & \end{array}$ & $\begin{array}{l}\text { au revenu annuel supérieur } \\
\text { à ... }\end{array}$ & $\begin{array}{l}\text {... et leur contribution au produit } \\
\text { de l'IR }\end{array}$ \\
\hline & $20 \%$ & $8800 €$ & $0,0 \%$ \\
\hline & $25 \%$ & $12250 €$ & $0,1 \%$ \\
\hline
\end{tabular}




\begin{tabular}{|l|l|l|l|}
\hline & $30 \%$ & $16150 €$ & $0,7 \%$ \\
\hline & $35 \%$ & $19600 €$ & $1,8 \%$ \\
\hline
\end{tabular}

Source : BMF / IWD, n 49/04.

2 Les nouvelles dispositions fiscales ne modifient qu'à la marge la structure de l'imposition des différentes tranches de revenus. Les $10 \%$ de foyers fiscaux aux revenus annuels supérieurs à $67000 €$ recensés outre-Rhin continuent ainsi de contribuer pour une large moitié au produit de l'IR. A l'opposé, le quart des foyers allemands déclarant moins de $12250 €$ par an est désormais pratiquement exonéré. (IB)

INDEX

Mots-clés : fiscalité, Impôt, réforme, revenu, salaire 